\title{
Formation of safety conditions for development of deposits by open mining
}

\author{
Oleh Anisimov ${ }^{1 *}$, Volodymyr Symonenko ${ }^{1}$, Oleksii Cherniaiev ${ }^{2}$, and Oleksandr Shustov ${ }^{1}$ \\ ${ }^{1}$ National Mining University, Department of Surface Mining, 19 Yavornytskoho Ave., 49005 Dnipro, \\ Ukraine \\ ${ }^{2}$ Institute for the Design of Mining Enterprises, National Mining University, 19 Yavornytskoho Ave., \\ 49005 Dnipro, Ukraine
}

\begin{abstract}
The researched parameters of the catching device, which ensures the safe operation of equipment and working people in deep open pits, where are formed the benches by steep dipping layers. For obtaining the results, the following methods were used: analytical - in determining existing devices for the capture of rocks; geometric - in determining the direction of the flight of blocks, semigraphical - in plotting and analyzing them. The modern technological catching devices, their structure, construction are analyzed. These structures protective devices can be used in deep pits in the development of deposits. Analytical dependence of the height of the jump the block of rock after hitting about a horizontal surface is improved, which takes into account the rate of falling and the angle of rebound the block, the elasticity of the surface. Creating of catching designs which capture the blocks of rock in the falling from the upper horizons in open pits allows to operate safely the mining equipment and to save the lives of workers. Especially this is important in the development of deposits by steep dipping layers. Proposed solutions can improve the safe using of dump trucks and moving workers in the work zone in the mining ledges of height over 30 meters.
\end{abstract}

\section{Introduction}

In the process of working off the deposit, the working area of the open pit develops with the movement of some ledges on the boundary contours. There is a need to ensure the safe operation of equipment and people on the lower horizons of the open pit, especially in areas prone to destruction. The assessment of the local stability rockfalling slopes of the ledges should be made on the basis of quantitative and qualitative characteristics of crevice the rock, with the composition of the forecast of the intensity of precipitation of weathering products and the size of the rock blocks, taking into account the possible seismic effect as a result of blasting operations.

Permanent movement of working benches reduces the risk of violations of their integrity from slowly occurring deformations. But artificially made blocking out layers and blocks make a number of additional conditions that reduce resistance.

\footnotetext{
* Corresponding author: ipgpnmu@ukr.net
} 
Rockfalls and inrushes are the most widely distributed types of violations of the steep benches and slopes of the ledges in rock and semi-rocky, which have substantial crevice (block structure). Caving and falling of individual blocks are usually prepared in advance by the breakdown of solid bundles of the rock in the form of gradually growing and deep cracks. The same rockfalls occur with catastrophic speed. Movement of the rock is accompanied by its overturning and rolling, sometimes with jumps on preventive berms and on other obstacles. Processes of weathering, penetration of water into the cracks, any dynamic loads and shakes contribute to the rockfalls. Among the latter, the greatest destruction of them is accompanied by seismic phenomena, which are caused, in contrast to the natural - organization of blasting operations.

The development of deformations of rock masses in benches of open pits takes a certain period of time, as and the occurrence of violations of stability. Any violation of the stability, even the caving of the mass, has a "hidden" stage of preparation, in the course of which there is a consistent destruction of numerous structural connections of rocks.

The weathering of rocks in the slope zones of the open pits is based on the development in time talus of the slopes formed mainly hard rocks. The following factors influence the development of the talus: angle of slope the bench, the intensity of crevice and the orientation of cracks to the top bench, the methods of preparation the benches, the technology of drilling and blasting operations, the climatic conditions of the area, the material composition of rocks.

There is a tendency to increasing the angle of slope of the non-working edges of the benches to $70-75^{\circ}$. This is due to the fact that the slight flattening out of the angles of the slopes the edges with further deepening of the bottom the open pit leads to a significant increasing in the volume of overburden removing, which is calculated in millions of cubic meters. There are the following types of deformations: talus, caving, rockfalls of individual plots in the shale deposits of iron-ore open pits [1,2].

Taluses are observed almost on all the horizons of deep open pits. In case of their untimely liquidation the pit edge may have a kind of continuous slope of high altitude, which creates a danger for the equipment and people at the lower benches.

The above resulted the relevance of the problem and the need to study the parameters of catching devices in terms of working off deep open pits with the construction of heavy pitching benches.

Decisions on the formation of stable pit edges were discussed in the publications of G. Feesenko, A. Shaparya, E. Galustyana, A. Lomtadze, S. Polischuk, V. Simonenko, A. Halperin, Parham Ashaier, V. Kaiumova and others.

The width of preventive berms in open pits can be reduced significantly as a result of the application of special methods for protecting the lower horizons from rockfalls [3]. These methods can be divided into two groups: prevention of deformations slopes of benches; the formation of preventive berms of special construction and rock catching devices. This theme for iron-ore open pits is not completely considered and requires additional researches.

On the basis of the analyzed data systematization of non-ore deposits in the scientific work [3] was conducted to determine the rational technological scheme for the development of useful minerals in a steep digging layer on non-ore open pits. The results of the above researches are reflected in the established dependences between the parameters of the system of development [4]. On their basis are determined the efficiency of the application of a selected technological scheme of working off rock in a steep digging layer. This also allows to determine the basic parameters of the steep layers that influence the size of the working area. 
The main indicators of the blocks that roll and fall from a significant height are determined in the research of V. Kaiumova. However, too high rates of their jump $(6 \mathrm{~m})$, calculated on a computer program are ambiguous.

In the work of Parham Ashaier an analysis and modeling of rockfall processes in different conditions were carried out [5]. Including enabled software complexes that reproduce the process of falling and the trajectory of the movement of blocks during the falling and rebound from the surface.

The analysis of various literary sources related with the studying of safe catching devices allows us to conclude that it is necessary to improve existing methods of their determination [6-11].

The formation of steep slopes layers during the development of deep open pits is accompanied by the positioning the areas of the benches in the temporary non-operating position and the formation of a single slope in the height more than $30 \mathrm{~m}$. In this case, there is a need for the safe placement of equipment on the lower horizons. During mining, untimely preparation the slopes of benches leads to significant self-caving of the solid mass and the falling of individual blocks. The working area should be protected from such negative manifestations, which is achieved by the creation of catching devices near the slope. The question arises how far a device should be created and what height it should be to protect workers and equipment.

\section{Method of carrying out the researches}

Methods of strengthening the slopes of the benches prone to rockfalls and overbreaks of the individual pieces the rock can be used only on the areas of the pit edges, where the work is complete and the edge is placed in the limit position. In the conditions of open pit working areas, the formation of permanent catching and fortified constructions with the using metal elements is undesirable. This is due to that the minerals are subject to further processing at the enrichment plants. In the process of crushing and grinding there will be problems with removal of metal remnants of reinforcing constructions. Therefore, the strengthening of rocks in the working area of the open pit may be concrete blends.

According to the recommendations of the Union research institute of transport construction, it is possible to determine the rate of rock fragmentation and its trajectory when falling from the slope with very steep slopes, which corresponds to the proposed technology of working out the open pit and the construction of heavy pitching benches. The estimated velocity of the debris for a monotonous slope along the straight profile is determined by the formulas for a section with very steep slopes more than $60^{\circ}$ and height of slope more than $10 \mathrm{~m}$.

The angle of slope of the lower part is formed as a result of the falling of small rock pieces on horizontal platforms (shelves), and also the spillage on basis the bench, which is formed from the small fractions as a result of erosion processes, the conducting of blasting operations in an open pit, etc.

The air resistance can be disregarded for the calculation of a rockfalling from a conditionally small height in most cases. The falling of the rock fragment with its displacement-along the slopes of the benches has three types of fall rates. The first is determined by the height of the cut-off from the slope of the ledge $\left(v_{p}\right)$, the second - occurs when the stone falls from the height and the impact on the intermediate horizontal plane with a slope formed by the spillages $\left(v_{t(0)}\right)$. After reflection from the intermediate platform, the rubble strikes the horizontal area of the lower bench and reflects from it with the third type of velocity $(U)$ (Fig. 1). 


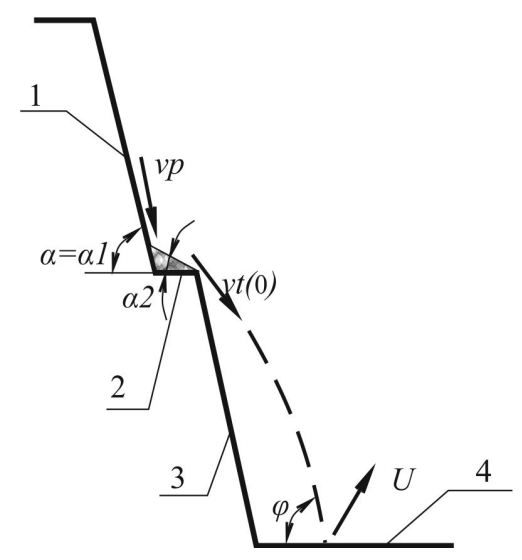

Fig. 1. Scheme of the movement of a rock rubble with the directions of speed at the points of change trajectory: 1 - the upper slope (the place of the chipping off a piece of rock; 2 - an intermediate area, covered by spillages; 3 - the lower slope; 4 - the lower area.

The overall dimensions of the in-depth catching shelves and the height of the soil shaft (m) for capturing blocks of rock should check the possibility of jumping the debris under their falling using the formula B. Kaiumova:

$$
h_{\max }=\frac{U^{2}}{2 g} \rho^{2} \sin ^{2} \phi,
$$

where $h_{\max }$ is the calculated height of jumping the rubble, $\mathrm{m} ; \varphi$ is the angle at which a rubble of rock falls on a horizontal surface, degrees.

Instead of the calculated rate of falling $U$ it is proposed to substitute the speed resulting after the impact on the earth's surface. With absolutely elastic impact and the absence of impact friction, the speed of the material point before and after the impact is the same, and the incidence angle is equal to the angle of reflection. At the moment after impact on the vertical surface, the height of the jumping of a rock piece can be determined by the formula:

$$
h_{\max }=\frac{\left(V_{y} \cdot \cos \alpha_{3} \sqrt{\operatorname{tg}^{2} \alpha_{3}+K^{2}}\right)^{2}}{2 g} \sin ^{2} \phi,
$$

where $\alpha_{3}$ is the angle between the vertical component and the trajectory of the flight of the rubble at the time of impact, degrees $\left(\alpha_{3}=90-\varphi\right) ; \varphi$ is the angle between the horizontal surface of the trajectory of the rubble at the time of falling, degrees; $K$ is the coefficient taking into account the elasticity of the surface $(K=1$ is the impact is absolutely elastic; $K=0$ is the impact is absolutely not elastic; $0<K<1$ is the impact is partially elastic; $V_{y}$ is the rate of falling of a stone at the moment of impact on the horizontal surface, $\mathrm{m} / \mathrm{s}\left(V_{y}=v_{t(0)}\right)$.

\section{Results}

On the basis of the given method, calculations were made and schemes of the trajectories of the movement rock block after collision with the intermediate horizontal platform on different horizons, and also the distance of their landing from the lower platform were obtained. The width of the platform is $2 \mathrm{~m}$. The angle of slope is $75^{\circ}$. The diameter of the 
boulders is $0.5 \mathrm{~m}$. The example of the obtained graphic images at height of slope $45 \mathrm{~m}$ and the working off benches at height $15 \mathrm{~m}$ is presented in Fig. 2.

Similar calculations were performed for areas of height 40 -meter (height of bench is $10 \mathrm{~m}$ ), $48 \mathrm{~m}$ (the height of the bench is $12 \mathrm{~m}$ ) and $40 \mathrm{~m}$ (the height of the bench is $20 \mathrm{~m}$ ).

On the basis of received calculations and graphic images a table is prepared showing the distance of the flight of rock rubbles from the lower crest of bench and the possible height of their jumping on the lower platform at different angles of incidence. According to the calculations, in the formation of slopes with angles of 70 to 75 degrees, at the specified height of the slopes and temporarily inoperative their sections, the average indicators of the required width of the catching area in the basis of slopes and the height of the catching construction in the conditions of working out steep deeping extraction layers are established (Fig. 3) On average, a safe area from falling blocks is at a distance of $3.96 \mathrm{~m}$ from the lower crest of the bench, and the height of the catching construction should be not less than $2.37 \mathrm{~m}$. Spillages, which are formed on intermediate horizontal platforms of open pits, in most cases, there is no possibility to clean, or need to hire rock climbers and manually clear the spillages. The work of climbers in such conditions is dangerous and costs considerable expenses for the mining enterprise.

$a$

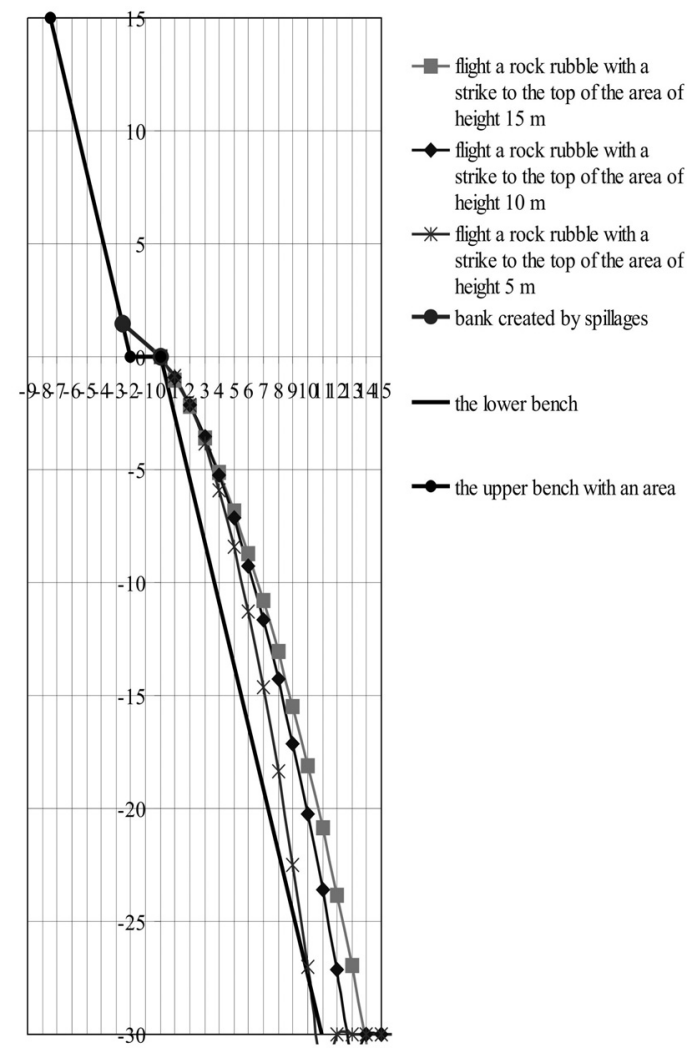

$b$

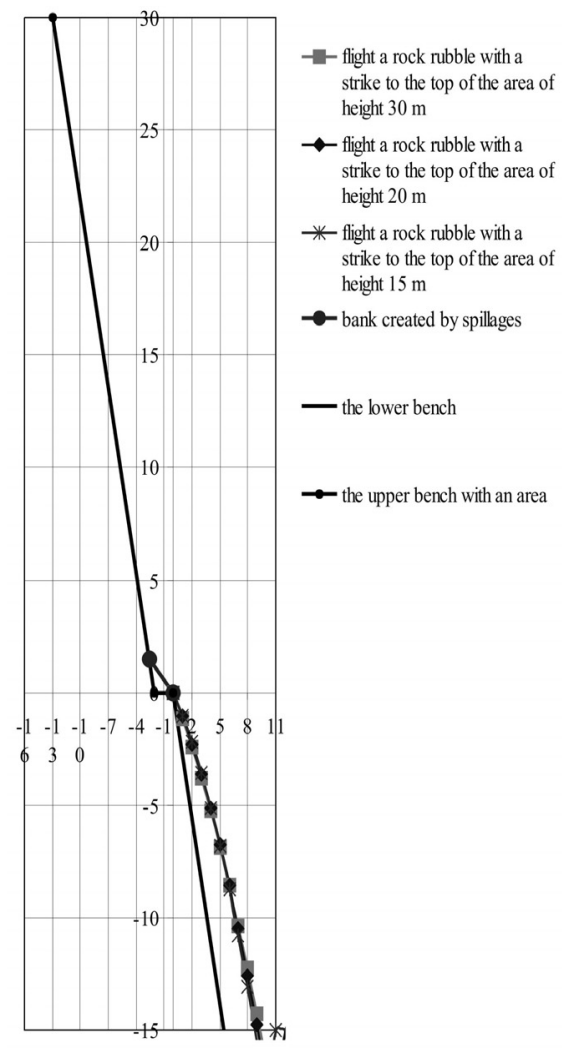

Fig. 2. Schemes of the trajectory the movement of rock rubble from a height 45,40 and $35 \mathrm{~m}$ at different positions of the intermediate platform between the benches of height $15 \mathrm{~m}$ : a-intermediate platform at altitude of $30 \mathrm{~m}$; b - intermediate platform at altitude of $15 \mathrm{~m}$. 


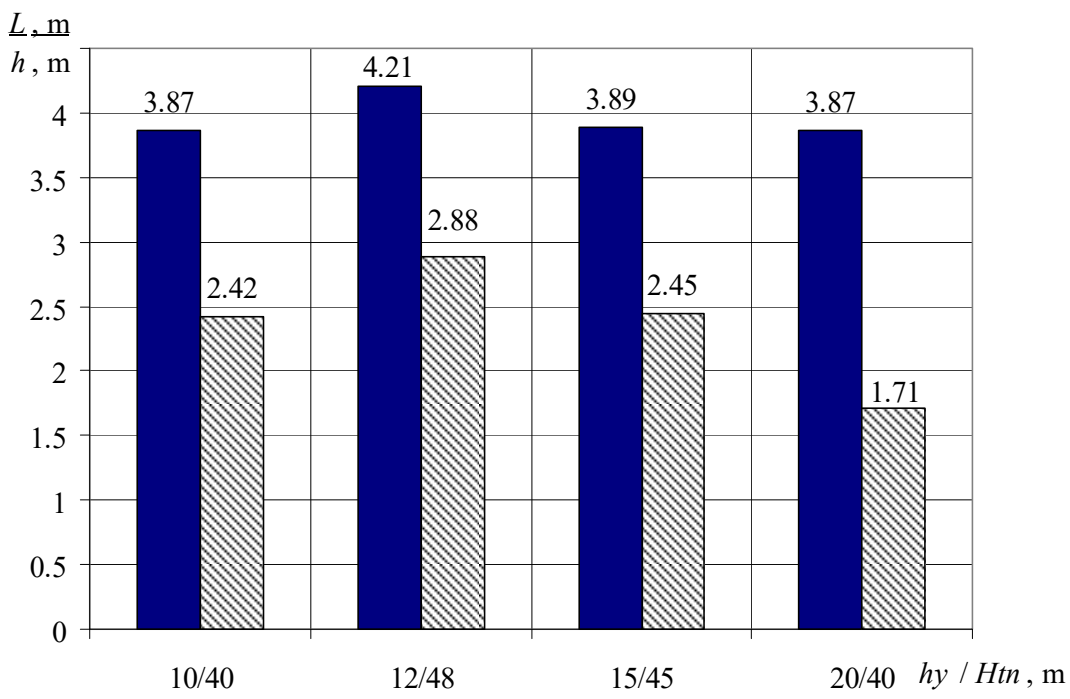

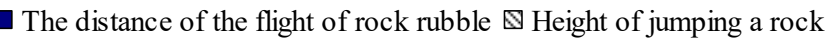

Fig. 3. Schedules of the distance the flight of rock rubbles and height of their rebound from the base of the face toe/bench bottom.

As can be seen from the table at working out individual benches of height $10 \mathrm{~m}$ and staging a section of the edge of height $40 \mathrm{~m}$ in a temporarily nonworking position, a rubble of rock that falls from the upper slopes of the bench, can land at a distance of $3.87 \mathrm{~m}$ and bounce from the ledger wall to height $2.42 \mathrm{~m}$.

At working out the mountain masses by the benches of height $12 \mathrm{~m}$ with the possible building of a section of the edge of height till $48 \mathrm{~m}$ in a temporarily nonworking position, a rubble of rock that falls from the upper slopes of the bench, can land at a distance of $4.21 \mathrm{~m}$ from lower crest of bench and bounce from the ledger wall to height $2.88 \mathrm{~m}$. The development of benches of $20 \mathrm{~m}$ high and their doubling till $40 \mathrm{~m}$ requires the establishment of safe boundaries from falling of rubbles at a distance of not less than $3.87 \mathrm{~m}$ from the lower crest of bench. At the same time, a possible ricochet can lead to a jumping of a piece to height $1.71 \mathrm{~m}$. The benches of height $15 \mathrm{~m}$ with the setting in a temporarily non-operating position of a plot of $45 \mathrm{~m}$ height requires taking into account the safe location of the enclosing construction at a distance of $3.89 \mathrm{~m}$ from the lower crest of the lower bench. In this case, according to the above calculations there is a ricochet of a rubble rock with a jumping to height $2.45 \mathrm{~m}$.

The obtained parameters allow, at given parameters of the working benches, to form catching and anti-caving constructions, which will protect industrial objects and workers in the working area of the open pit.

The retaining constructions should be foreseen to prevent shifts, rockfalls and inrushes of rubbles rock if it is impossible or economically inexpediency to change the size of the slope bench. In this case, retaining constructions are used in the form of:

- supporting walls - for strengthening the uplifting rock cornices;

- buttresses - separate supports, which are cut into stable layers of the rock for support of separate rock masses;

- supports - massive constructions to support unstable slope bench;

- facing walls - for prevention rocks from weathering and caving; 
- fillings in the form of backfill cavities formed as a result of inrushes on slopes - for prevention rock from weathering and further destruction;

- anchoring - set as independent retaining constructions (with supporting slabs, beams, etc.) or in the form of fastening of separate rock blocks to a solid massif.

Table 1. Estimated values of distance of movement rock rubbles at falling from the upper benches of development the rock.

\begin{tabular}{|c|c|c|c|c|c|}
\hline $\begin{array}{l}\text { Height of } \\
\text { slope of pit } \\
\text { edge/height } \\
\text { of bench, m }\end{array}$ & $\begin{array}{l}\text { The height of } \\
\text { the separation } \\
\text { the rubble } \\
\text { over the } \\
\text { intermediate } \\
\text { area, } m\end{array}$ & $\begin{array}{l}\text { The placement } \\
\text { of an } \\
\text { intermediate } \\
\text { platform with } \\
\text { spillages in } \\
\text { height, } m\end{array}$ & $\begin{array}{l}\text { Angle of } \\
\text { reflection of a } \\
\text { rubble on the } \\
\text { lower area, } \\
\text { degrees* }\end{array}$ & $\begin{array}{l}\text { The distance } \\
\text { of falling a } \\
\text { rubble from } \\
\text { the lower edge } \\
\text { of the lower } \\
\text { bench, } \mathrm{m}^{*}\end{array}$ & $\begin{array}{c}\text { Height of } \\
\text { jumping a } \\
\text { rubble on } \\
\text { the lower } \\
\text { area, m* }\end{array}$ \\
\hline \multirow{9}{*}{$40 / 10$} & 10 & 30 & $78 / 72$ & $1.85 / 1.83$ & $0.91 / 0.91$ \\
\hline & 8 & 30 & $79 / 73$ & $1.36 / 1.14$ & $0.74 / 0.74$ \\
\hline & 5 & 30 & 80/slope & $0.32 /$ slope & $0.47 /$ slope \\
\hline & 20 & 20 & $73 / 65$ & $3.14 / 3.87$ & $1.71 / 1.66$ \\
\hline & 10 & 20 & $76 / 69$ & $2.29 / 2.65$ & $0.88 / 0.87$ \\
\hline & 5 & 20 & $78 / 73$ & $1.22 / 1.12$ & $0.45 / 0.46$ \\
\hline & 30 & 10 & $69 / 61$ & $2.42 / 3.16$ & $2.42 / 2.34$ \\
\hline & 20 & 10 & $69 / 60$ & $2.38 / 3.11$ & $1.61 / 1.55$ \\
\hline & 10 & 10 & $72 / 65$ & $2.12 / 2.66$ & $0.85 / 0.82$ \\
\hline \multirow{3}{*}{$40 / 20$} & 20 & 20 & $73 / 66$ & $3.12 / 3.87$ & $1.71 / 1.66$ \\
\hline & 10 & 20 & $76 / 69$ & $2.29 / 2.66$ & $0.88 / 0.87$ \\
\hline & 5 & 20 & $79 / 73$ & $1.22 / 1.12$ & $0.46 / 0.46$ \\
\hline \multirow{6}{*}{$45 / 15$} & 15 & 30 & $77 / 70$ & $2.68 / 2.98$ & $1.33 / 1.32$ \\
\hline & 10 & 30 & $78 / 72$ & $1.84 / 1.83$ & $0.91 / 0.91$ \\
\hline & 5 & 30 & 81/slope & $0.32 /$ slope & $0.47 /$ slope \\
\hline & 30 & 15 & $70 / 62$ & $3.04 / 3.89$ & $2.45 / 2.38$ \\
\hline & 20 & 15 & $72 / 64$ & $2.89 / 3.64$ & $1.67 / 1.63$ \\
\hline & 15 & 15 & $74 / 66$ & $2.69 / 3.34$ & $1.28 / 1.25$ \\
\hline \multirow{9}{*}{$48 / 12$} & 12 & 36 & $78 / 73$ & $1.87 / 1.74$ & $1.09 / 1.1$ \\
\hline & 10 & 36 & $79 / 73$ & $1.42 / 1.13$ & $0.91 / 0.92$ \\
\hline & 5 & 36 & slope & slope & slope \\
\hline & 24 & 24 & $74 / 67$ & $3.42 / 4.21$ & $2.07 / 2.03$ \\
\hline & 12 & 24 & $77 / 71$ & $2.47 / 2.81$ & $1.08 / 1.07$ \\
\hline & 6 & 24 & $79 / 73$ & $1.23 / 1.09$ & $0.55 / 0.55$ \\
\hline & 36 & 12 & $68 / 60$ & $2.74 / 3.48$ & $2.88 / 2.78$ \\
\hline & 24 & 12 & $70 / 62$ & $2.69 / 3.43$ & $1.96 / 1.89$ \\
\hline & 12 & 12 & $73 / 66$ & $2.34 / 2.98$ & $1.03 / 1.00$ \\
\hline
\end{tabular}

Notice: * calculations are made at angles of slopes the benches 75 degrees/70 degrees; slope means that the rubble fells not on the horizontal platform, but on the slope of the bench; the width of the intermediate platform between the benches is $2 \mathrm{~m}$.

Retaining constructions in the conditions of a deep open pit can be arranged in the upper zone of open pit after the mine working on the design contours. Such constructions can be used on slopes near capital transport communications, near transshipment points, technological platforms of traffic, etc. The working area of the open pit changes constantly its position. In such conditions, the most reliable safety devices are small, movable catching devices that can be moved during moving the mining front on the bench.

Catching constructions and devices (walls, grids, shafts, trenches, shelves with retaining walls, spiles) should be provided for the protection of objects against the impact of talus, inrushes, falling of individual rock fragments, as well as rockfalls in that case if their 
warning or the arrangement of retaining constructions is impossible or economically inexpediently. Catching walls and grids are located at the ledger wall of slopes the benches, having angles more than $25-35^{\circ}$.

Catching trenches and shelves with a curb wall should be placed at the ledger wall of dangerous slopes the group of benches of height $60 \mathrm{~m}$ and steepness more than $35^{\circ}$ for protection from the inrushes of individual rock debris volume till $1 \mathrm{~m}^{3}$. The constructions of the main anti-caving devices and equipment are shown in Fig. $4-7$.

Stationary protective devices (Fig. 5a, b) or anchoring are located only on areas that are no more involved in the development. This is due to the fact that the timbering consists of metal products. The anchors, as well as other timbering, remain in the slopes and can be adversely affected on the technological process of crushing in the event of their entry into the crusher. The placement of such timbering will be made on the finished slopes of the overburden rocks.

$a$

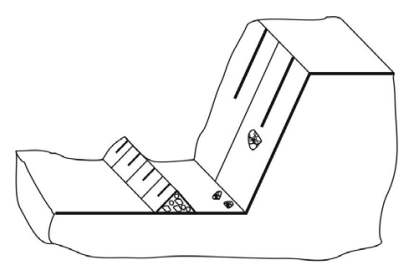

$b$

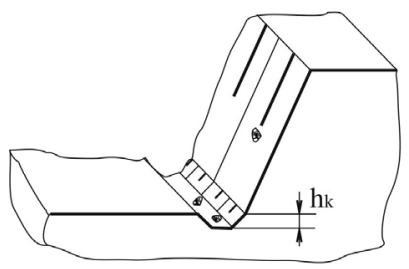

C

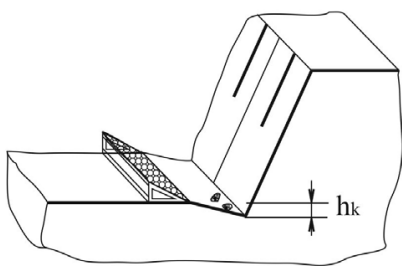

Fig. 4. Constructions of anti-caving catching constructions: a - ground shaft; $b$ - catching ditch (drain); c-displaced mesh of the sloping construction: $h_{k}$ - depth of the ditch, $\mathrm{m}$.

$a$

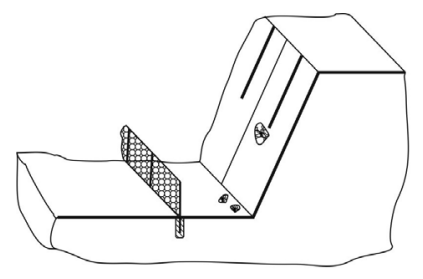

$b$

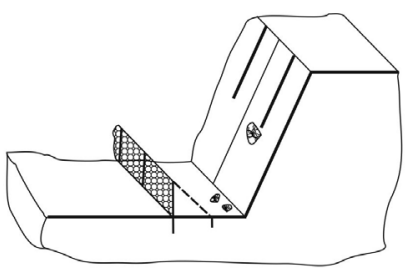

$c$

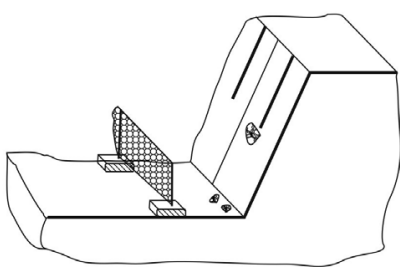

Fig. 5. Constructions of anti-caving catching meshes: a - stationary with concrete foundation; $b-$ stationary with the strengthening of flexible traction; $\mathrm{c}$ - mobile (movable).

$a$

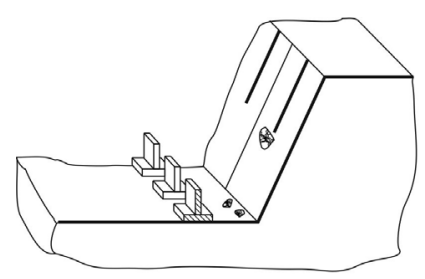

$b$

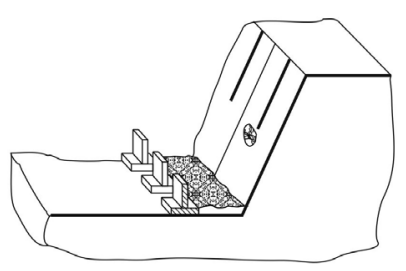

$c$

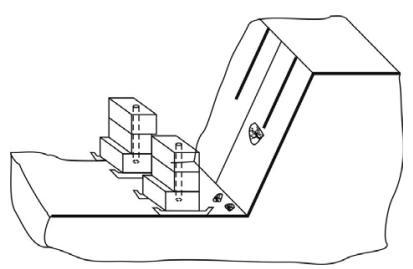

Fig. 6. Constructions of anti-caving catching, mobile concrete constructions: a - concrete blockscatchers; $\mathrm{b}$ - concrete catchers with a soft "pillow"; $\mathrm{c}$ - mobile movable concrete blocks. 
$a$

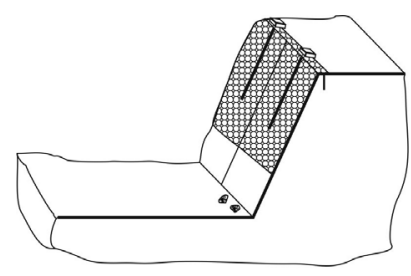

$b$

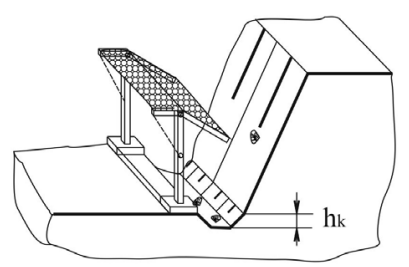

$c$

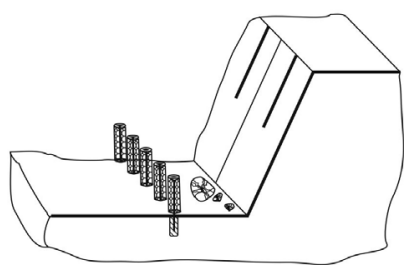

Fig. 7. Constructions of anti-caving devices: $a-a$ mesh on the surface of slope the bench; $b$ - mobile devices; $\mathrm{c}$ - rolls of a wound mesh on a concrete rod.

The most dangerous plots of the working areas are the places of traffic dumping trucks near the slopes above the bench. Under the action of dynamic loads and during drilling and blasting operations, the slope of the bench gradually loses its stable properties. Debris is cut off from the rock mass, which roll down. With significant dimensions, they have a great destructive power that can damage the equipment and are dangerous for workers in the open pits.

Widely accepted method of control with rockfalls of slopes the benches are shafts, ditches, timbering with a mesh and others. The disadvantage of the construction of retaining shafts is the need for their placement with considerable width and height at the loading platform near the lower crest of the upper bench. The height of the retaining shaft is $3-4 \mathrm{~m}$ or more, depending on the height and slope of the bench, and is constructed on a platform in the width of $4-6 \mathrm{~m}$. The constructions of such shafts complicate the cleaning spillages.

For the purpose of improving the designs of devices that catch debris of rolling rock, a scheme is proposed for protection the plot on the non-working of the pit edge. Due to the improvement and introduction of new constructive solutions is attained significant reducing the width of the transport platform and protection the dumping trucks from falling large rock blocks, and, due to this, reducing the volume of mining capital operations on arrangement of temporarily non-working benches in the working zone. In addition, the placement of such constructions in the working zone allows the excavator to operate safely on the removal and loading into dumping trucks and other types of transport, used in deep open pits.

The new design of the protective device is mobile, which is very relevant in the working area of the open pit. As needed, this device can move around the working platform and be located near the lower crest of the bench. The moving of the construction is carried out using the stripes at the base of the device and the bulldozer. The bulldozer is used as auxiliary equipment. The principle of operation of the protective device is based on the accumulated rock mass in the stretched grid/mesh, with subsequent unloading it under the influence of rock weight and forces of gravity into the ditch. The metal grid/mesh allows to quench the energy of movement of individual blocks and catch them during the falling. The mobility of the catching device allows to move it following the mining work on the bench. As the rock masses accumulate in the ditch, the device moves toward the side and cleaning of the ditch is carried out with the using an excavator (Fig. 8). The excavator with the help of a bucket removes rock fragments from the ditch and places them on the plot or loads in dumping trucks. After cleaning the bottom part of the slope, the device returns to its place. 


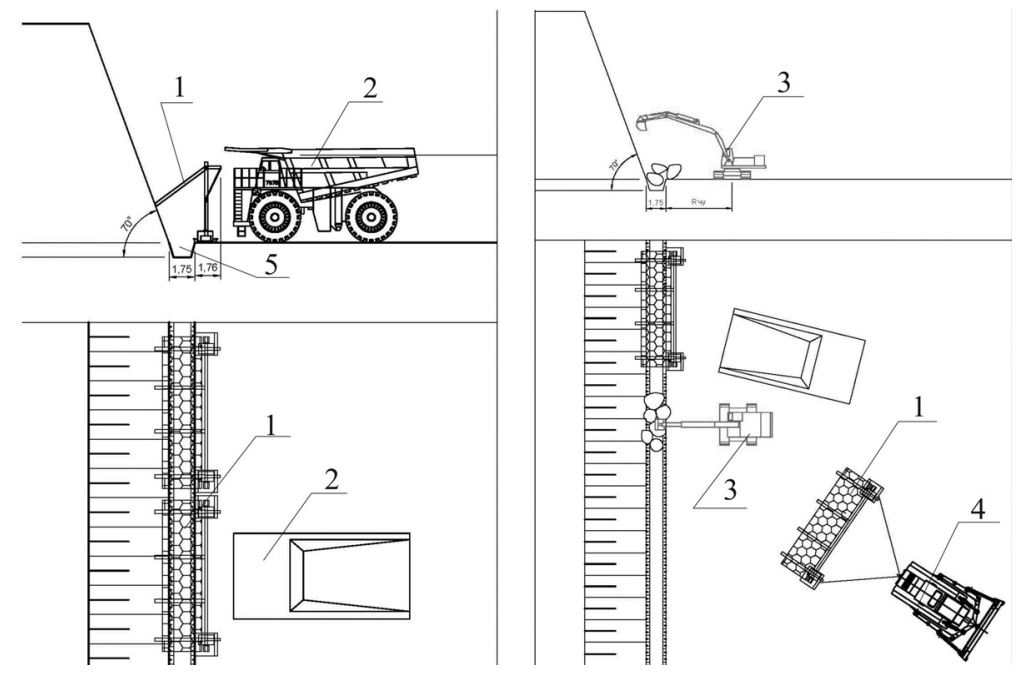

Fig. 8. Schemes for placing the protective device and cleaning the catching area from the rock blocks that fall down: 1 - a device for protecting the platform; 2 - an open pit dumping truck; 3 - excavator; 4 - bulldozer; 5 - catching ditch (drain).

The proposed design allows to reduce the width of the working platform and to protect dumping trucks from the falling of rock blocks. Dumping trucks carry out maneuvers of turning and movement on the working platform, and also people who may be in this zone. Compared to the fixing of the surface by a mesh throughout the plane of the slope, it allows to get a significant savings of material and monetary resources.

\section{Conclusions}

Thus, the formation of safe conditions for the formation of steep dipping excavation layers is possible due to mobile anti-caving devices, which allows to reduce the width of the working platform on 3-4 m, and according to reduce the volume of removal of the overburden rock. The proposed solutions allow to increase the safe using of dumping trucks and the movement of workers in the working area during working out the benches of the height more than $30 \mathrm{~m}$. The safe area from falling blocks is at a distance of at least $4 \mathrm{~m}$ from the lower crest of bench where the trajectory of the movement reaches the highest point, and the height of the catching construction in this point must be at least $2.5 \mathrm{~m}$ from the horizontal plot of the bench.

These researches are carried out in the framework of the research work "Development of technological bases of ecologically safe mining in the technologically-loaded mining regions of Ukraine" (State registration No. 0117U001134).

\section{References}

1. Anisimov, O.A. (2015). Tehnologiya stroitelstva $i$ razrabotki glubokikh kar'yerov. Dnipropetrovsk: Natsionalnyi hirnychyi universytet.

2. Abdellah, W.R., Beblawy, M.M., \& Mohamed, M.T. (2018). Evaluation of open pit slope stability using various slope angles and element types. Mining of Mineral Deposits, 12(2), 47-57. https://doi.org/10.15407/mining12.02.047 
3. Cherniaiev, O. (2017). Systematization non-metallic deposits of rocky minerals for improvements technologies of their development. Naukovyi Visnyk Natsionalnoho Hirnychoho Universytetu, (5), 11-17.

4. Symonenko, V., Cherniaiev, O., \& Hrytsenko, L. (2016). Organization of non-metallic deposits development by steep excavation layers. Mining of Mineral Deposits, 10(4), 68-73. https://doi.org/10.15407/mining10.04.068/

5. Parham Ashayer (2007). Application of rigid body impact mechanics and discrete element modeling to rockfall simulation. Department of Civil Engineering. University of Toronto.

6. Anisimov, O. (2018). Research on parameters of the working area on an internal dump for developing open pits. Naukovyi Visnyk Natsionalnoho Hirnychoho Universytetu, (1), 27-34. https://doi.org/10.29202/nvngu/2018-1/17/

7. Anisimov, O. (2015). The development of deep pits steep slope layers. Theoretical and Practical Solutions of Mineral Resources Mining, 243-246. ISBN:978-1-315-64877-4.

8. Cherniaiev, O. (2017). Systematization of the hard rock non-metallic mineral deposits for improvement of their mining technologies. Naukovyi Visnyk Natsionalnoho Hirnychoho Universytetu, (5), 11-17.

9. Gorova, A., Pavlychenko, A., Borysovs'ka, O., \& Krups'ka, L. (2013). The development of methodology for assessment of environmental risk degree in mining regions, Annual ScientificTechnical Collection - Mining of Mineral Deposits, 207-209.

10. Saik, P., Petlevanyi, M., Lozynskyi, V., Sai, K., \& Merzlikin, A. (2018). Innovative approach to the integrated use of energy resources of underground coal gasification. Solid State Phenomena, (277), 221-231. https://doi.org/10.4028/www.scientific.net/SSP.277.221

11. Shirin, L.N., Denishchenko, A.V., Yurchenko, O.O., \& Mikhalev, D.V. (2012). Methodology for determination of rope vehicles energy consumption. Naukovyi Visnyk Natsionalnoho Hirnychoho Universytetu, (4), 464-469.

12. Pivnyak, G.G., \& Shashenko, O.M. (2015). Innovations and safety for coal mines in Ukraine. Naukovyi Visnyk Natsionalnoho Hirnychoho Universytetu, (6), 118-121. 